\title{
Pengaruh Manajemen Pengetahuan Terhadap Peningkatan Inovasi Dan Kualitas Pelayanan RSUD Kabupaten Serang
}

\author{
Riyan M. Faris, Heti Mulyati, dan Elisa Anggraeni \\ Fakultas Ekonomi Dan Manajemen Institut Pertanian Bogor University \\ Email: riyanmirdan@gmail.com
}

\begin{abstract}
This study aims to determine and analyze the role of knowledge management in improving innovation and service quality, as well as analyzing the effect of innovation on service quality in the Drajatprawiranegara regional hospital in Serang Regency. In this study the analysis of data processing using Structural Equation Modeling - Partial Least Square (SEM-PLS). The results of the analysis (SEM-PLS) explain that there is an influence between knowledge management on innovation where the application of optimal knowledge management will increase innovation in the health service process. There is a significant indirect effect between knowledge management on service quality, but innovation influences service quality. Therefore human resource management in Drajat Prawiranegara hospital must be carried out comprehensively. Cooperation between fields of work, be it medical, doctor and non-medical workers must be optimal in facing challenges and demands from changing health services.
\end{abstract}

Keywords: knowledge management, innovation, service quality, SEM-PLS.

\begin{abstract}
Abstrak: Penelitian ini bertujuan untuk mengetahui dan menganalisis peran manajemen pengetahuan dalam meningkatkan inovasi dan kualitas pelayanan, serta menganalisis pengaruh inovasi terhadap kualitas pelayanan di rumah sakit daerah drajatprawiranegara Kabupaten Serang. Dalam penelitian ini analisis pengolahan data menggunakan Structural Equation Modeling - Partial Least Square (SEM-PLS). Hasil dari analisis (SEM-PLS) menjelaskan bahwa terdapat pengaruh antara manajemen pengetahuan terhadap inovasi dimana dengan penerapan manajemen pengetahuan yang optimal akan meningkatkan inovasi dalam proses pelayanan kesehatan. Terdapat pengaruh tidak langsung yang signifikan antara manajemen pengetahuan terhadap kualitas pelayanan, akan tetapi inovasi memberikan pengaruh terhadap kualitas pelayanan. Maka dari itu pengelolaan sumber daya manusia di rumah sakit Drajat Prawiranegara harus dilakukan secara komperhensif. Kerja sama antar bidang kerja, baik itu tenaga kerja medis, dokter dan non medis harus optimal dalam menghadapi tantangan serta tuntutan dari perubahan pelayanan kesehatan.
\end{abstract}

Kata kunci: manajemen pengetahuan, inovasi, kualitas pelayanan, SEM-PLS.

\section{PENDAHULUAN}

Pengelolaan sumberdaya pada industri jasa merupakan hal yang perlu diperhatikan ketika perubahan lingkungan sangat cepat serta kompleks. Rumah sakit merupakan salah satu industri jasa kesehatan yang harus mampu beradaptasi dalam menghadapi perubahan tersebut, baik yang berasal dari faktor internal maupun eksternal. Faktor internal yang 
dapat mempengaruhi perubahan yaitu pengelolaan sumber daya manusia (SDM) dan pengelolaan aktivitas. Faktor eksternal yang dapat mempengaruhi perubahan yaitu kebijakan pemerintah daerah, teknologi terbaru, dan demografi. Sumber daya manusia pada rumah sakit dituntut agar dapat beradaptasi dengan perubahan tersebut.

Proses pelayanan kesehatan merupakan layanan inti atau layanan primer dalam pelayanan rumah sakit yang ditentukan oleh sumberdaya manusia didalamnya (Padma et al., 2013). Manusia menjadi salah satu sumber daya yang penting di rumah sakit yang mampu mengaplikasikan fungsi perencanaan, pengorganisasian, pengarahan serta pengendalian terhadap berbagai tugas manajemen kesehatan (Townsend dan Wilkinson, 2010). Sumber daya manusia yang terdapat di rumah sakit meliputi keseluruhan tenaga medis dan non medis. Agar dapat mewujudkan terciptanya pelayanan kesehatan yang berkualitas diperlukan tenaga kesehatan yang memiliki kemampuan intelektual, teknikal dan interpersonal, bekerja berdasarkan standar praktik (Hafizurrachman, 2012). Peran tenaga medis dan non medis dituntut untuk lebih profesional dan tepat dalam menangani berbagai kasus medis. Sistem manajemen pengetahuan dan inovasi yang tepat dapat mendukung pekerjaan tenaga medis dalam menangani pasien dan membantu dalam pengambilan keputusan, sehingga kesalahan dalam penangan dapat dihindari. Pemerintah daerah sebagai penyelenggara pemerintahan sudah tentu harus turut andil dalam menanggapi pelayanan kesehatan yang ada di daerah dengan cara memberikan dukungan kepada rumah sakit daerah dalam meningkatkan pelayanan kesehatan bagi masyarakat. Hal ini juga yang menjadi perhatian khusus bagi pemerintah kabupaten Serang. Rumah sakit daerah Kabupaten Serang dipilih menjadi tempat penelitian karena merupakan rumah sakit percontohan bagi kabupaten dan kota di seluruh Provinsi Banten.

Jumlah rumah sakit di kabupaten Serang sebanyak 4 (empat) buah yaitu Rumah Sakit Hermina Ciruas, Rumah Sakit Kurnia Serang, Rumah Sakit Ibu dan Anak Permata Serdang dan Rumah Sakit Umum Daerah Drajat Prawiranegara Kabupaten Serang. Rumah sakit yang dikelola oleh pemerintah setempat yaitu Rumah Sakit Umum Daerah Drajat Prawiranegara. Oleh karena itu, Pemerintah Kabupaten Serang memberi perhatian khusus agar dapat melayani pasien secara optimal. Pengembangan RSUD Drajatprawiranegara Kabupaten Serang menjadi rumah sakit yang profesional dan bertumbuh, harus sejalan dengan kemampuan dalam beradaptasi terhadap tuntutan lingkungan. Perubahan inovasi dipahami sebagai sebuah proses dimana organisasi menciptakan dan menentukan masalah. Pihak rumah sakit harus secara aktif mengembangkan pengetahuan baru, untuk menyelesaikan permasalahan yang ada. Pengetahuan inilah yang menjadi intangible aset atau aset tidak berwujud berupa pengetahuan bagi kemajuan RSUD Kabupaten Serang.

Manajemen pengetahuan sangat berperan dalam persaingan yang dialami RSUD Drajatprawiranegara Kabupaten Serang dalam meningkatkan kualitas pelayanan tenaga kerjanya. Semakin tinggi tingkat pengetahuan tenaga kerja rumah sakit tersebut, maka mudah untuk mengikuti perubahan kearah yang lebih baik sesuai dengan tugasnya. Dengan demikian diperlukan suatu sistem dan tata kelola yang dapat menciptakan nilai dari aset pengetahuan. manajemen pengetahuan dalam pelayanan kesehatan dibutuhkan bagi penyedia pelayanan kesehatan dalam meningkatkan kualitas pelayanan (Jussi, 2012). Manajemen pengetahuan berperan penting untuk mendukung proses inovasi dalam kegiatan bisnis dengan dukungan implementasi manajemen pengetahuan yang efektif (Ing-Long, 2018). Apabila sistem dan tata kelola manajemen pengetahuan RSUD Kabupaten Serang ditingkatkan dengan cara mendukung tenaga kerja untuk melakukan 
pembelajaran dalam konteks individu maupun organisasi hal ini merupakan cara yang efektif dalam meningkatkan inovasi dan kualitas pelayanan.

Kunjungan rawat jalan dan inap RSUD Kabupaten Serang Tahun 2012 sampai 2017 cenderung mengalami peningkatan. Hal tersebut merupakan tantangan agar rumah sakit mampu memberikan pelayanan kesehatan yang optimal. Salah satu cara untuk meningkatkan pelayanan kesehatan adalah melalui inovasi dalam pelayanan kesehatan sehingga lebih efisien dan efektif.

Gambar 1. kunjungan rawat jalan dan inap RSUD Kabupaten Serang Tahun 2012- 2017.

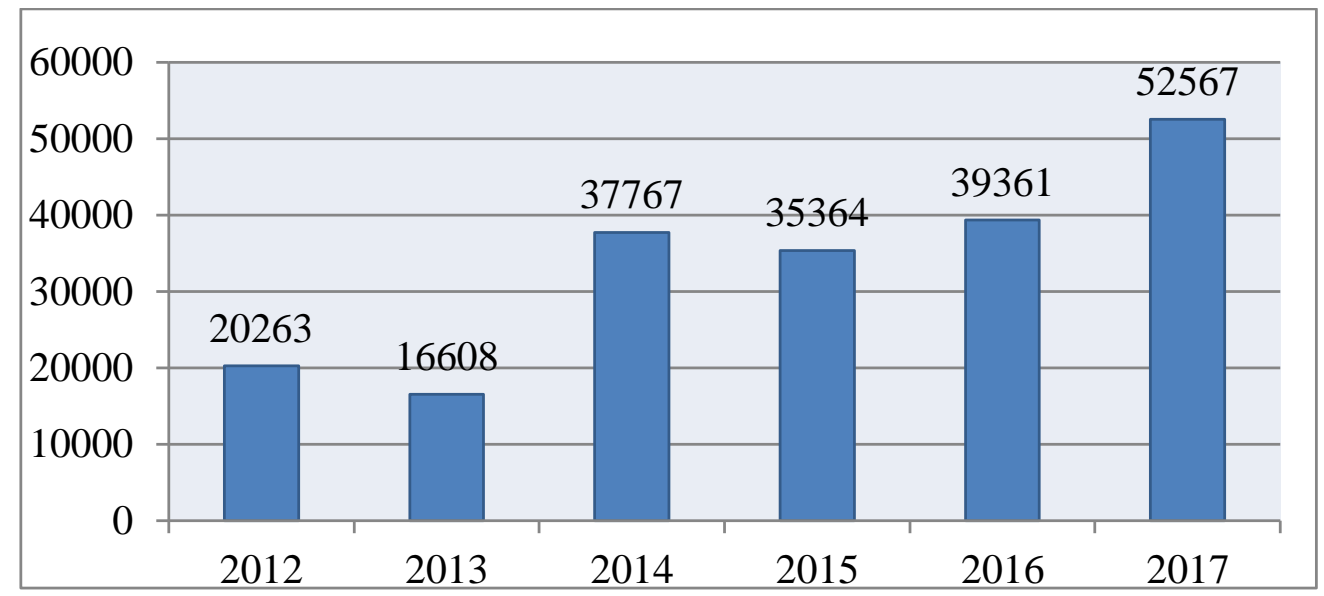

Sumber: RSUD Kabupaten Serang

Tingkat pentingnya inovasi kolaboratif dalam pengembangan daya saing organisasi semakin diakui di era modern (Xiaomi, 2014) pengelolaan sumber daya yang inovatif dalam sistem layanan dapat menciptakan nilai tinggi dalam kualitas pelayanan (Edvardsson dan Bard, 2013). Inovasi di sektor pelayanan kesehatan merupakan salah satu jalan untuk mengatasi kemacetan serta kebuntuan dalam suatu organisasi di sektor pelayanan kesehatan. Sistem yang kaku dan kurang efisien yang telah menjadi karakteristik sistem di sektor pelayanan kesehatan harus mampu dicairkan oleh budaya inovasi. Pengembangan model kualitas layanan inovatif dapat dikembangkan apabila inovasi terus berjalan dengan baik (Hamzani, 2015). Inovasi yang biasanya hanya akrab di lingkungan dinamis seperti di sektor bisnis perlahan harus mulai disuntikan ke sektor publik dalam hal ini sektor pelayanan kesehatan. Hal terebut juga dilakukan oleh RSUD Prawiranegara Kabupaten Serang dalam memberikan pelayanan kepada pengguna jasanya.

Tabel 1. Jenis inovasi proses pelayanan di Rumah Sakit Umum Daerah Drajat Prawiranegara Kabupaten Serang.

\begin{tabular}{c|l|l|l}
\hline No. & Jenis Inovasi & \multicolumn{1}{c}{ Sasaran } & \multicolumn{1}{c}{ Keterangan } \\
\hline 1. & Pembayaran satu pintu & $\begin{array}{l}\text { Pengguna } \\
\text { layanan } \\
\text { Rumah Sakit }\end{array}$ & $\begin{array}{l}\text { Sistem pembayaran dari berbagai } \\
\text { unit layanan bisa dilakukan di satu } \\
\text { pintu bagian administrasi }\end{array}$ \\
\hline
\end{tabular}




\begin{tabular}{c|l|l|l}
\hline 2. & $\begin{array}{l}\text { Pendaftaran layanan } \\
\text { kesehatan terpisah bagi } \\
\text { kelompok rentan }\end{array}$ & $\begin{array}{l}\text { Ibu hamil } \\
\text { dan anak- } \\
\text { anak }\end{array}$ & $\begin{array}{l}\text { Tersedia loket khusus untuk } \\
\text { kemudahan pelayanan bagi ibu hamil } \\
\text { dan anak-anak (kelompok rentan) }\end{array}$ \\
\hline 3. & Helper & $\begin{array}{l}\text { Pengguna } \\
\text { layanan } \\
\text { Rumah Sakit }\end{array}$ & $\begin{array}{l}\text { Petugas rumah sakit pada jam-jam } \\
\text { tertentu berkeliling dan siap } \\
\text { membantu pasien di lingkungan } \\
\text { rumah sakit }\end{array}$ \\
\hline 4. & Hotline Service & $\begin{array}{l}\text { Pengguna } \\
\text { layanan } \\
\text { Rumah Sakit }\end{array}$ & $\begin{array}{l}\text { Pengguna layanan kesehatan dapat } \\
\text { dengan mudah mengakses informasi } \\
\text { serta memberikan kritik terkait } \\
\text { dengan prosedur pelayanan } \\
\text { kesehatan melalui nomor hotline } \\
\text { service yang sudah terpasang } \\
\text { disetiap sudut ruangan }\end{array}$ \\
\hline
\end{tabular}

Sumber: RSUD Kabupaten Serang

Berdasarkan Tabel 1 inovasi proses pelayanan yang dilakukan RSUD Kabupaten Serang antara lain pelayanan pembayaran satu pintu yang sesuai dengan efisiensi layanan, pelayanan pendaftran antrian tersendiri bagi kelompok rentan yang termasuk dalam kemudahan akses layanan, helper yang termasuk dalam aspek service delivery, dan yang terakhir adalah hotline service yang termasuk dalam kemudahan layanan.

Dari data yang ditemukan di lapangan dapat diketahui yang melatar belakangi RSUD Kabupaten Serang melakukan inovasi dalam proses pelayanan yaitu untuk meningkatkan kualitas pelayanan dari tenaga kerjanya dan untuk kepuasan pengguna layanan kesehatan di RSUD Kabupaten Serang. Inovasi mempunyai sifat mendasar yaitu kebaruan bagi suatu organisasi. Manajemen pengetahuan berperan penting didalam proses kebaruan dalam organisasi kebaruan ini juga akan menggantikan pengetahuan, cara dan teknologi yang lama dan sudah tidak efektif dalam menangani permasalahan di sekitar lingkungan organisasi.

Hasil observasi dan wawancara kepada dua tenaga kerja inovasi di Rumah Sakit Umum Daerah Drajat Prawiranegara Kabupaten Serang masih lambat dan kurang optimal dalam implementasi. ini dibuktikan dengan dalam kurun waktu lima tahun terakhir sampai tahun 2017 rumah sakit baru melaksanakan inovasi dalam proses pelayanan. Inovasi yang dilakukan oleh RSUD Kabupaten Serang tersebut berada dalam jenis inovasi proses pelayanan yang di dalam penerapannya diharapkan inovasi tersebut dapat meningkatkan kualitas pelayanan. Berdasarkan data yang didapatkan antara lain adalah inovasi pelayanan jasa.

Penelitian ini bertujuan untuk (1) menganalisis penerapan manajemen pengetahuan dalam meningkatkan inovasi dan kualitas pelayanan tenaga kerja di Rumah Sakit Umum Daerah Drajatprawiranegara Kabupaten Serang. (2) menganalisis pengaruh manajemen pengetahuan terhadap inovasi dan kualitas pelayanan tenaga kerja di Rumah Sakit Umum Daerah Drajatprawiranegara Kabupaten Serang. (3) menganalisis pengaruh inovasi terhadap kulitas pelayanan tenaga kerja Rumah Sakit Umum Daerah Drajatprawiranegara Kabupaten Serang. 


\section{KAJIAN TEORI}

Manajemen Pengetahuan. (Luthans, 2006) mendefinisikan manajemen pengetahuan (knowledge management) sebagai perkembangan alat, proses, sistem, struktur dan budaya secara eksplisit untuk meningkatkan pembuatan, pembagian, dan penggunaan pengetahuan yang kritis untuk pengambilan keputusan, lebih lanjut menyatakan secara umum ada dua model untuk merepresentasikan knowledge management dalam literature dan praktik aktual diantaranya; aset pengetahuan terwujud (tangible) yang tercakup dan dipertahankan dalam struktur dan sistem organisasi, dan aset pengetahuan tidak berwujud (intangible) atau inteligensi yang dimiliki karyawan dan stakeholder sedangkan, (Dalkir, 2005) mendefinisikan knowledge management sebagai koordinasi yang disengaja dan sistematis dari orang-orang di dalam organisasi, teknologi, proses, dan struktur organisasi dalam rangka untuk menambah nilai melalui pemakaian ulang dan inovasi. Definisi lain diungkapkan oleh (Jennex, 2007) knowledge management adalah praktik dari penerapan pengetahuan secara selektif dari pengalaman pengambilan keputusan sebelumnya untuk aktivitas pengambilan keputusan saat ini dan masa depan.

Manajemen pengetahuan memiliki tiga pilihan peran yang bisa dilakukan, yaitu (1) manajemen pengetahuan mempunyai peran mengelola pengetahuan, mengosentrasikan diri dalam kodifikasi pengetahuan dan menempatkannya dalam reposisi pengetahuan yang dapat diakses oleh karyawan sesuai dengan otoritasnya; (2) manajemen pengetahuan diarahkan untuk mempertemukan antara orang yang memiliki pengetahuan dengan orang yang membutuhkan pengetahuan dengan identifikasi sesuai dengan kebutuhannya masingmasing; (3) manajemen pengetahuan mengombinasikan antara pilihan pertama dan pilihan kedua, menumbuhkan sumber daya yang lebih besar, karena jika sumber daya tidak cukup maka pengelolaan pengetahuan bisa menjadi stagnan dan tidak fokus (Nawawi, 2012).

Menurut (Huang et al., 2013) mengatakan bahwa manajemen pengetahuan adalah proses mencari, mengelola dan mendistribusikan pengetahuan untuk setiap anggota organisasi. Menurut (Nonaka dan Takeuchi, 2004) manajemen pengetahuan dapat diubah menjadi empat jenis, yaitu sosialisasi, eksternalisasi, kombinasi dan internalisasi. (1) Sosialisasi, merupakan proses interaksi antara sumber daya manusia atau modal insani didalam organisasi yang dilakukan dengan pertemuan langsung seperti misalnya rapat dan diskusi. Melalui hal tersebut setiap anggota organisasi dapat berbagi pengetahuan dan pengalaman-pengalaman industri yang dimilikinya sehingga adanya pertukaran pengetahuan dan menciptakan pengetahuan yang baru bagi mereka. (2) Eksternalisasi, hal ini merupakan proses untuk mengartikulasi tacit pengetahuan menjadi suatu konsep yang jelas sehingga pengetahuan tacit tersebut dapat menjadi pengetahuan eksplisit yang dapat diakses atau dipelajari oleh semua anggota organisasi. Proses ini biasanya dilakukan ketika adanya sosialisasi. (3) Kombinasi, proses ini merupakan proses untuk menyusun semua pengetahuan yang sudah terdokumentasikan kedalam sistem manajemen pengetahuan. Media dalam proses ini dapat melalui forum diskusi (intranet), dan database organisasi. (4) Internalisasi, proses ini adalah proses dimana semua data, informasi, yang sudah menjadi pengetahuan didokumentasikan dan disajikan kepada setiap anggota organisasi agar semua anggota organisasi dapat mempelajari semua pengetahuan yang ada. Dalam proses inilah terjadi peningkatan pengetahuan pada sumber daya manusia. 
Gambar 2. Model konversi pengetahuan SECI proses

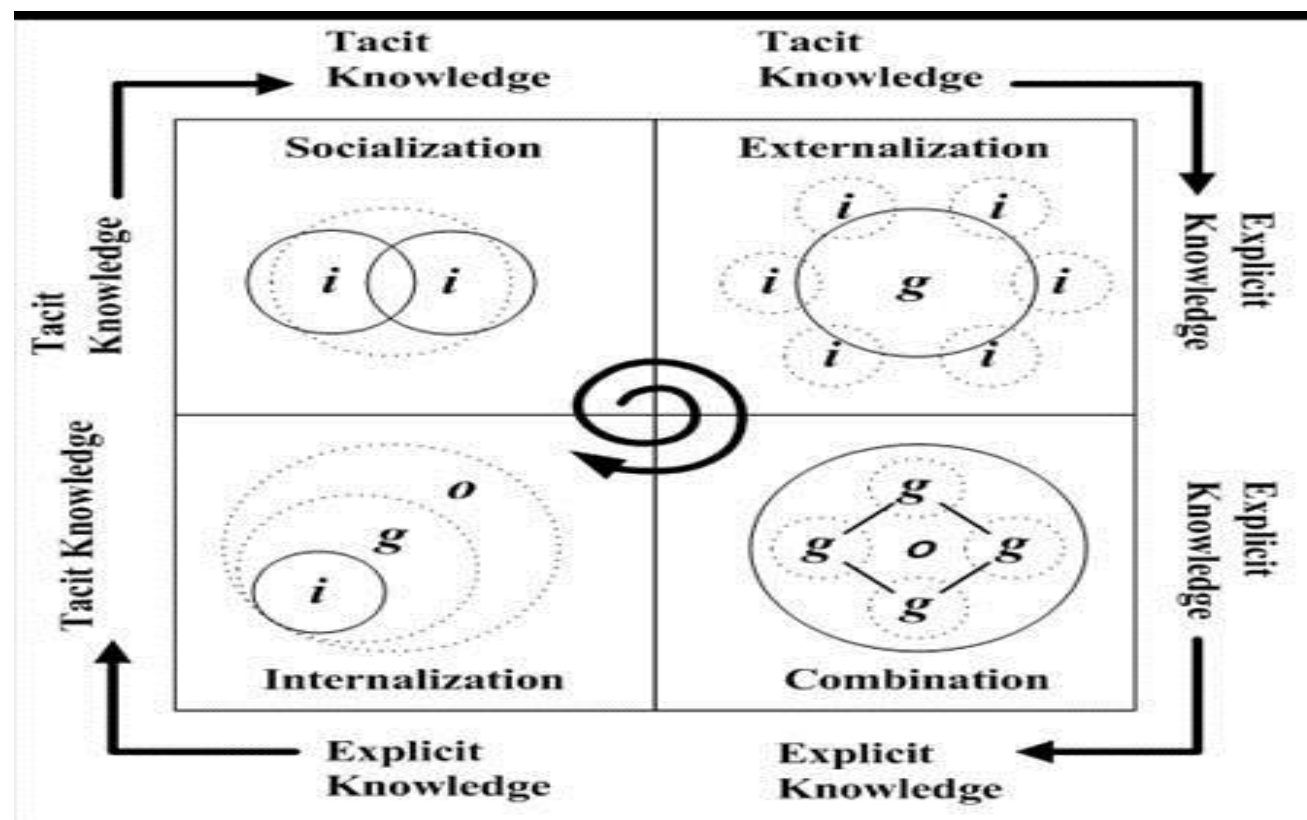

(Nonaka dan Takeuchi, 1995)

Inovasi Inovasi merupakan istilah yang telah dipakai secara luas dalam berbagai bidang, Inovasi secara umum dipahami dalam konteks perubahan perilaku. Inovasi biasanya erat kaitannya dengan lingkungan yang berkarakteristik dinamis dan berkembang. Pengertian inovasi sendiri sangat beragam, dan dari banyak perspektif. Menurut (Rogers, 2003) salah satu penulis buku inovasi terkemuka, menjelaskan inovasi adalah sebuah ide, praktik, atau objek yang dianggap baru oleh individu satu unit adopsi lainnya. Oleh karena itu penting bagi penyedia jasa kesehatan yaitu rumah sakit dalam menciptakan ide baru dalam setiap kegiatan pelayanan kesehatan. Inovasi dalam pelayanan jasa kesehatan bertujuan untuk memuaskan pengguna jasanya yaitu pasien rawat inap dan rawat jalan. Pengertian inovasi akhirnya memang menjadi luas tetapi pada dasarnya inovasi merupakan suatau proses yang tidak hanya sebatas menciptakan ide atau pemikiran baru. Ide tersebut harus diimpelementasikan melalui sebuah proses adopsi, adopsi adalah keputusan untuk menggunakan inovasi secara keseluruhan sebagai cara tindakan yang terbaik. Proses adopsi inovasi inilah yang harus mendapat perhatian utama oleh sebuah organisasi. Inovasi adalah sebuah perubahan (change), baik berupa perubahan dalam produk dan jasa, maupun perubahan dalam proses, jika dilihat dari sifat perubahannya, dapat dibedakan pada perubahan secara bertahap (incremental), radikal (radical), atau perubahan bentuk (transformation) Tidd (2001). Menurut (Salim dan Sulaeman, 2013) dimensi inovasi di dalam konsep manajemen perubahan dan inovasi dibagi menjadi empat inovasi (4Ps Innovation) yaitu: (1) Inovasi produk, merupakan perubahan dalam hal produk atau jasa yang ditawarkan oleh organisasi. (2) Inovasi proses, merupakan perubahan dalam cara bekerja/membuat produk dan cara melakukan distribusinya. (3) Inovasi positioning, merupakan perubahan dalam konteks memperkenalkan produk atau jasa perusahaan. (4) Inovasi paradigma, merupakan perubahan dalam pola atau metode yang ada didalam kerangka organisasi. 
Kualitas Pelayanan Rumah sakit adalah organisasi jasa kesehatan yang ber-fungsi melayani kesehatan masyarakat. Kualitas pelayanan rumah sakit di Indonesia masih dirasakan kurang memuaskan. Beberapa keluhan yang muncul disebabkan adanya perbedaan persepsi mengenai pelayanan yang dirasakan oleh pasien rawat inap di kelas 3 dengan di VIP. Keluhan terjadi bukan hanya pada aspek infrastruktur, namun juga pelayanan dari Sumber Daya Manusianya. Waktu tunggu pasien untuk dilayani seringkali sangat terlambat dan tidak sesuai dengan jadwal praktik yang sudah ditetapkan (Jonirasmanto 2009). Preferrensi pasien dapat mengubah kriteria kualitas pelayanan kesehatan di rumah sakit. Oleh karena itu pihak rumah sakit sebagai penyedia layanan kesehatan harus dapat terus memantau preferensi pasien, sehingga dapat mempersepsikan kriteria kualitas pelayanan yang optimal. Pentingnya mengukur kualitas pelayanan karena kepuasan pasien ditentukan oleh kualitas pelayanan yang dirasakannya (Duggirala et al., 2008). (Choi, 2006) menyatakan bahwa, kualitas pelayanan merupakan kesan relatif mengenai tingkat inferioritas atau superioritas dari organisasi dan karyawannya. Di lain pihak, (Mukherjee dan Malhotra, 2006), mendefinisikan kualitas pelayanan sebagai hasil dari interaksi antar manusia yaitu antara pemberi jasa dengan konsumen. Pengertian lain mengenai kualitas pelayanan yaitu sebagai sebuah harapan, keinginan yang ingin disampaikan oleh penyedia layanan dalam bidang jasa, standar ideal, harapan normatif, pelayanan yang diutamakan dan tingkat pelayanan optimal yang diharapkan oleh konsumen

\section{METODOLOGI}

Dalam penelitian ini terdapat dua variabel yaitu variabel independen atau variabel yang dapat mempengaruhi dan variabel dependen atau variabel yang hanya dapat dipengaruhi. Penelitian ini bertujuan untuk mengetahui serta membuktikan apakah terdapat pengaruh antara manajemen pengetahuan dan inovasi sebagai variabel independen terhadap kualitas pelayanan sebagai variabel dependen. Dalam penelitian ini analisis pengolahan data menggunakan Structural Equation Modeling - Partial Least Square (SEM-PLS). Jenis data yang digunakan yaitu data primer, berupa wawancara serta jawaban langsung dari responden yang dilakukan di rumah sakit daerah drajatprawiranegara Kabupaten Serang dan data sekunder yaitu data yang sudah diolah melalui studi pustaka didalam penelitian ini. Sampel dalam penelitian ini berjumlah 91 responden dengan prosedur pengambilan sampel didasarkan pada non - probability sampling dengan jenis sampling yang digunakan adalah purposive sampling. Dalam penelitian ini, terdapat dua variabel yang digunakan yaitu yaitu variabel eksogen atau variabel independen dan variabel endogen atau variabel dependen. variabel dalam penelitian ini akan Membagi masing-masing variabel menjadi variabel oprasional atau indikator hal ini bertujuan agar setiap variabel dapat diukur dan dianalisis. Lebih rinci lagi, berikut adalah masing-masing variabel beserta indikator didlam penelitian ini. 
Tabel 2. Variabel laten dan Indikator

\begin{tabular}{|c|c|c|}
\hline No & Variabel Laten & Indikator \\
\hline \multirow[t]{4}{*}{1} & \multirow[t]{4}{*}{ Manajemen Pengetahuan } & proses mendapatkan pengetahuan \\
\hline & & proses memilih pengetahuan \\
\hline & & proses berbagi pengetahuan \\
\hline & & proses penerapan pengetahuan \\
\hline \multirow[t]{6}{*}{2} & \multirow[t]{6}{*}{ Inovasi } & $\begin{array}{c}\text { pelayanan baru atau pelayanan yang } \\
\text { diperbaiki }\end{array}$ \\
\hline & & inovasi proses \\
\hline & & inovasi bersifat administratif \\
\hline & & inovasi sistem \\
\hline & & inovasi konseptual \\
\hline & & perubahan radikal \\
\hline \multirow{8}{*}{3} & \multirow{8}{*}{ Kualitas Pelayanan } & Infrastruktur \\
\hline & & Kualitas Personel \\
\hline & & Proses Pelayanan \\
\hline & & Prosedur Administrasi \\
\hline & & Keselamatan \\
\hline & & Citra Rumah Sakit \\
\hline & & Tanggung Jawab Sosial \\
\hline & & Kepercayaan kepada Rumah Sakit \\
\hline
\end{tabular}

Sumber: (Data proses, 2019)

Selanjutnya dalam penelitian ini untuk menentukan tingkat kemampuan setiap variabel ditentukan dari semua data pertanyaan berupa kuisioner yang diambil dari setiap indikator. Penilaian setiap indikator ditentukan melalui skala likert satu sampai lima. Data yang sudah dikumpulkan akan di analisis menggunakan metode analisis data menggunakan Partial Least Square (PLS) yang diolah dengan software Smart PLS 3.0, dalam penelitian ini akan dilakukan evaluasi model PLS menggunakan software Smart PLS 3.0 yaitu pada outer model dan inner model. Dalam penelitian ini outer model digunakan untuk mengukur validitas dan reliabilitas model dalam penelitian. Sedangkan untuk mengetahui hubungan serta pengaruh bisa diukur dengan inner model dan dilakukan juga evaluasi model PLS untuk mengetahui bentuk dan seberapa besar pengaruh antar variabel laten independen (eksogen) dalam penelitian ini yaitu manajemen pengetahuan dan inovasi terhadap variabel dependen (eksogen) yaitu kualitas pelayanan. Model kerangka konseptual dalam penelitian ini dapat dilihat pada gambar 3. 
Gambar 3. Model konseptual

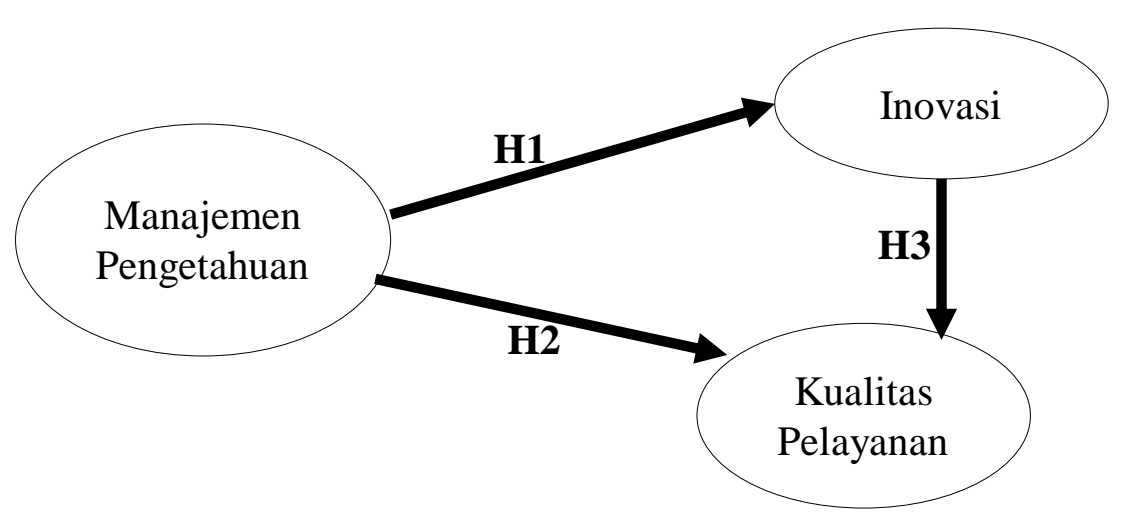

\section{HASIL DAN PEMBAHASAN}

Karakteristik responden. Dalam penelitian ini responden berasal dari seluruh tenaga kerja RSUD Drajat prawiranegara yang terdiri dari beberapa unit kerja yaitu tenaga keperawatan, tenaga kedokteran, dan tenaga non kesehatan yang menjawab pertanyaan berupa kuisioner. Responden yang sudah dilibatkan dalam penelitian ini yaitu sebanyak 91 tenaga kerja kemudian responden tersebut dipilih berdasarkan beberapa bagian yaitu jenis kalamin, pendidikan, unit kerja, dan usia. Pada Tabel 4 dibawah ini merupakan rekapitulasi data responden tenaga kerja RSUD Drajat Prawiranegara.

Hasil dari karakteristik responden bahwa pada penelitian ini jenis kelamin wanita secara nyata lebih besar dari pada responden berjenis kelamin pria hal ini dikarenakan sebagian besar tenaga kerja di RSUD Drajat Prawiranegara di dominasi perawat yang identik dengan wanita. Sedangkan pada karakteristik responden mengenai pendidikan terakhir dari responden RSUD Drajat Prawiranegara menunjukan bahwa lulusan D3 dan sarjana (S1) lebih banyak hal ini dikarenakan jumlah perawat dalam responden penelitian ini merupakan sarjana keperawatan (S1) dan D3 keperawatan (Amd). Berdasarkan unit kerja dari responden dalam penelitian ini keperawatan paling mendominasi yaitu sebesar $81.3 \%$ dan sisanya yaitu kedokteran $4.4 \%$ dan tenaga non kesehatan $14.3 \%$. Terdapat perbedaan yang nyata dari unit kerja hal ini dikarenakan jumlah tenaga kerja pada unit keperawatan RSUD Drajat Prawiranegara lebih banyak di bandingkan dengan unit kerja kedokteran dan non kesehatan Selanjutnya berdasarkan usia dari responden di dominasi usia muda yang aktif di unit kerja keperawatan yaitu paling banyak pada usia 20 sampai 30 tahun. Pihak RSUD Drajat Prawiranegara dalam hal usia harapannya dapat meningkatkan kualitas pelayanan yang baik.

Evaluasi Outer Model (Model Pengukuran). Dalam penelitian ini evaluasi outer model di analisis untuk mengukur validitas dan reliabilitas model. Penelitian ini menggunakan indikator yang reflektif pada semua variabel laten independen (eksogen) yaitu manajemen pengetahuan dan inovasi dan juga variabel laten dependen (eksogen) yang sesuai dengan teori pengukuran classical theory. Menurut (Ghozali, 2008) model indikator reflektif disebut principal factor model dimana konstruk laten mempengaruhi covariance pengukuran indikator dan mencerminkan variasi konstruk laten. 
Gambar 4. Diagram jalur model re-estimasi

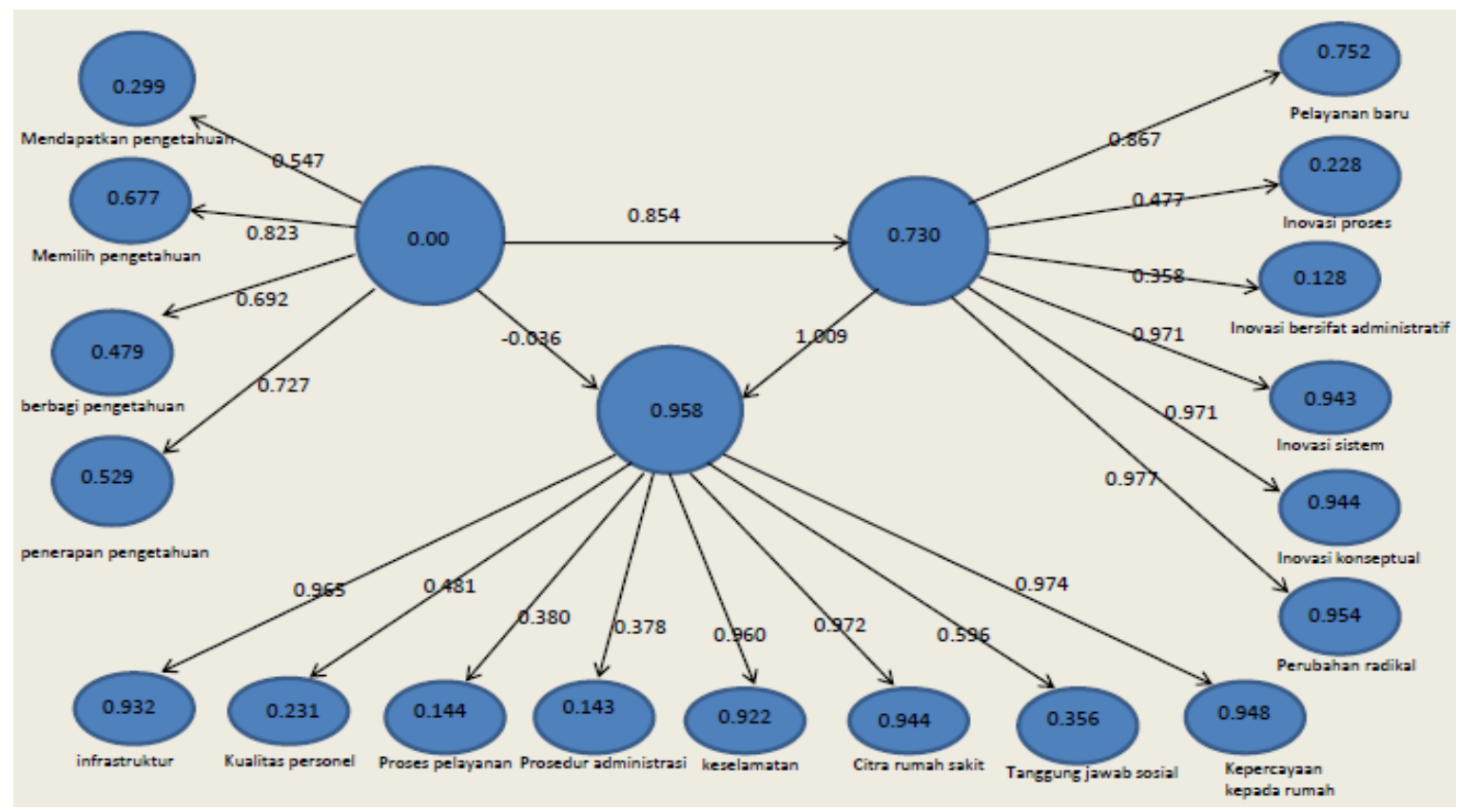

Pada gambar 4 diagram jalur model mencerminkan seluruh indikator reflektif valid. dalam analisis pengukuran outer model suatu indikator akan di eliminasi apabila tidak lolos kriteria dalam pengujian validitas dan juga reliabilitas. Apabila terdapat indikator yang di eliminasi atau dihilangkan hal ini tidak akan merubah nilai validitas variabel lainnya. Suatu indikator valid jika nilai yang didapatkan memiliki korelasi tinggi dari dua instrumen yang berbeda. Indikator bisa dikatakan valid atau lolos uji validitas jika nilai outer loading $>0.5$, serta nilai AVE dan communality $>0.5$. Untuk pengukuran reliabilitas dalam PLS dilihat dari nilai Composite Reliability suatu indikator dapat dikatakan reliabel apabila nilai Composite Reliability lebih besar dari 0.7 (Ghozali, 2008). Berdasarkan tabel 3 berikut diketahui bahwa seluruh kriteria outer model dalam penelitian ini sudah memenuhi syarat.

Tabel 3. Hasil evaluasi model pengukuran reflektif

\begin{tabular}{c|l|l}
\hline No & \multicolumn{1}{|c}{ Parameter } & \multicolumn{1}{c}{ Penilaian } \\
\hline 1 & Loading Factor & $\begin{array}{l}\text { Semua indikator memiliki Nilai Loading } \\
\text { Factor }>0.60\end{array}$ \\
\hline 2 & $\begin{array}{l}\text { Composite } \\
\text { Reliability }\end{array}$ & $\begin{array}{l}\text { Semua indikator memiliki Nilai Composite } \\
\text { Reliability }>0.60\end{array}$ \\
\hline 3 & $\begin{array}{l}\text { Avarage Variance } \\
\text { Reliability }\end{array}$ & Semua indikator memiliki AVE $>0.50$ \\
\hline 4 & $\begin{array}{l}\text { Validitas } \\
\text { Diskriminan }\end{array}$ & $\begin{array}{l}\text { Semua nilai akar kuadrat AVE dari peubah } \\
\text { laten, lebih besar dari korelasi peubah laten } \\
\text { lainnya }\end{array}$ \\
\hline 5 & Cross Loading & Semua indikator manajemen pengetahuan, \\
\hline
\end{tabular}




\begin{tabular}{l|l|l}
\hline & $\begin{array}{l}\text { inovasi dan kualitas pelayanan memiliki } \\
\text { korelasi yang lebih besar pada laten sendiri } \\
\text { daripada korelasi ke laten lainnya }\end{array}$ \\
\hline
\end{tabular}

Sumber: (Data proses,2019)

Dalam penelitian ini menngunakan analisis data second order confirmatory dimana setiap indikator mencerminkan masing-masing manifest variabel yang digunakan pada setiap indikator. Nilai loading factor merupakan nilai dari validitas, diharuskan lebih besar dari 0.5 untuk dikatakan valid dan jika nilai loading factor kurang dari 0.5 maka dikatakan tidak valid. Pada tabel 7 dan gambar 6 berikut hasil akhir dari nilai outer loading setelah re-estimasi dimana nilai outer loading semua indikator lebih dari 0.5 sehingga dapat disimpulkan bahwa semua indikator dalam penelitian ini valid.

variabel laten manajemen pengetahuan yang terdiri dari variabel manifest yaitu proses mendapatkan pengetahuan (X1.1), proses memilih pengetahuan (X2.2), proses berbagi pengetahuan (X1.3) dan proses penerapan pengetahuan (X1.4) seluruh indikator dari masing masing variabel sudah memenuhi standar loading factor yaitu lebih dari 0.5. hasil dari pengujian validitas menggambarkan nilai loading factor dari variabel manifest proses mendapatkan pengetahuan sebesar 0.860. Ini menunjukan bahwa didalam proses mendapatkan pengetahuan tenaga kerja RSUD Drajat prawiranegara sudah dilakukan dengan optimal. Variabel manifest proses memilih pengetahuan yang digambarkan dengan indikator yaitu X1.2.1, X1.2.2, dan X1.2.3 menunjukan hasil nilai terbesar loading factor sebesar 0.871. hal ini menunjukan bahwa seluruh tenaga kerja RSUD Drajat prawiranegara sudah memilih pengetahuan sesuai dengan bidangnya masingmasing. Begitu juga dengan variabel manifest proses berbagi pengetahuan yang menunjukan hasil terbesar dalam loading factor yaitu 0.785. Yang menunjukan bahwa dalam proses berbagi pengetahuan sudah dilakukan dengan optimal. Terakhir adalah variabel manifest proses penerapan pengetahuan yang menunjukan hasil loading factor tertinggi sebesar 0.762. Secara keseluruhan terdapat 12 indikator yang semuanya merefleksikan variabel laten manajemen pengetahuan. Hal ini memberikan gambaran bahwa penerapan manajemen pengetahuan menjadi hal penting bagi RSUD Drajat prawiranegara.

variabel laten inovasi yang dicerminkan variabel manifest yaitu Pelayanan baru atau pelayanan yang diperbaiki (X2.1), Inovasi proses (X2.2), Inovasi bersifat administrasi (X2.3), Inovasi sistem (X2.4), Inovasi konseptual (X2.5) dan Perubahan radikal (X2.6) hanya indikator dari variabel manifest inovasi proses (X2.2) yang indikatornya mengalami eliminasi dari model karena tidak memenuhi nilai standar dari loading factor. Untuk variabel manifest pelayanan baru atau pelayanan yang diperbaiki (X2.1) dicerminkan oleh 3 indikator yaitu X2.1.1, X2.1.2, dan X2.1.3, dari hasil ketiga indikator tersebut bahwa semua indikator dinyatakan valid karena memenuhi syarat loading factor. Indikator X2.1.2 mencerminkan nilai terbesar dengangan nilai loading factor sebesar 0.855. Sedangkan untuk variabel manifest inovasi proses (X2.2) dicerminkan oleh 2 indikator yang dinyatakan valid karena memenuhi syarat loading factor yaitu indikator X2.2.1 dan X2.2.2. dengan nilai loading factor sebesar 0.936. Serta variabel manifest lainnya yaitu inovasi bersifat administrasi (X2.3), Inovasi sistem (X2.4), Inovasi konseptual (X2.5) dan Perubahan radikal (X2.6) seluruh indikatornya valid. 
Variabel laten kualitas pelayanan yang dicerminkan variabel manifest yaitu Infrastruktur (Y1.1), Kualitas Personel (Y1.2), Proses Pelayanan (Y1.3), Prosedur Administrasi (Y1.4), Keselamatan (Y1.5), Citra Rumah Sakit (Y1.6), Tanggung Jawab Sosial (Y1.7), Kepercayaan kepada Rumah Sakit (Y1.8). Untuk variabel manifest infrastruktur di cerminkan oleh tiga indikator yaitu Y1.1.1,Y1.1.2 dan Y1.1.3, seluruh indikator valid karena memenuhi syarat nilai loading factor dengan nilai loading factor paling besar yaitu 0.870. Pada variabel manifest kualitas personel setelah dilakukan reestimasi dicerminkan oleh dua indikator yaitu Y1.2.1 dan Y1.2.2, kedua indikator tersebut dinyatakan valid karena memenuhi syarat nilai loading factor dengan nilai terbesar pada indikator Y1.2.1 sebesar 0.832. kemudian pada variabel manifest proses pelayanan dicerminkan oleh tiga indikator yaitu Y1.3.1, Y1.3.2 dan Y1.3.3, dari hasil ketiga indikator tersebut seluruhnya valid karena sudah memenuhi syarat nilai loading factor dengan nilai paling besar 0.865. Untuk variabel manifest prosedur administrasi keseluruhan indikatornya valid, terdapat tiga indikator yaitu Y1.4.1, Y1.4.2 dan Y1.4.3, dengan nilai loading factor paling besar pada indikator Y1.4.3. sebesar 0.869. pada variabel manifest keselamatan dicerminkan oleh tiga indikator yaitu Y1.5.1, Y1.5.2 dan Y1.5.3, ketiganya memenuhi syarat loading factor dengan indikator Y1.5.3 mencerminkan nilai terbesar yaitu 0.899 . Untuk variabel manifest selanjutnya yaitu citra rumah sakit dengan tiga indikator yaitu Y1.6.1, Y1.6.2 dan Y1.6.3, ketiga indikator tersebut valid karena sesuai dengan syarat nilai loading factor dengan nilai tertinggi sebesar 0.760. Sedangkan variabel manifest tanggung jawab sosial setelah dilakukan reestimasi yang dicerminkan oleh dua indikator yaitu Y1.7.1 dan Y1.7.2, variabel dinyatakan valid karena sesuai dengan syarat ketentuan loading factor dengan nilai terbesar yaitu 0.926. Serta yang terakhir yaitu variabel manifest kepercayaan kepada rumah sakit yang dicerminkan oleh tiga indikator yaitu Y1.8.1, Y1.8.2 dan Y1.8.3, dari hasil ketiga indikator tersebut dinyatakan valid karena memenuhi syarat loading factor dengan niali terbesar yaitu 0.785 .

Evaluasi Inner Model Setelah melakukan uji validitas dan uji reliabilitas dalam penelitian ini yang sudah memenuhi syarat dalam setiap uji validitas dan uji reliabilitas maka tahapan selanjutnya yaitu dilakukan evaluasi inner model. menurut (Gozali, 2008) analisis inner model bisa dilakukan dengan dua tahap kriteria yaitu $\mathrm{R}^{2}$ dari peubah laten endogen dan estimasi jalur. Model inner atau model struktural akan menunjukan bagaimana hubungan antar variabel laten. Pengukuran yang akan dipakai dalam evaluasi menggunakan smart PLS yaitu koefisien determinan (Uji $\left.\mathrm{R}^{2}\right)$ dan koefisien jalur ( $t$ value). Dalam penelitian ini nilai $\mathrm{R}^{2}$ dalam pengujian koefisien determinan memiliki nilai masing-masing variabel laten eksogen yaitu sebesar 0.729 untuk varabel laten eksogen inovasi dan 0.965 untuk variabel eksogen kualitas pelayanan. Artinya nilai $\mathrm{R}^{2}$ dari variabel laten inovasi dan kualitas pelayanan masuk pada kategori model baik karena kedua variabel tersebut memiliki nilai $\mathrm{R}^{2}$ lebih besar dari 0.67 . Hal ini juga menunjukan nahwa manajemen pengetahuan mampu menjelaskan keragaman variabel inovasi sebesar $72.9 \%$ dan sisanya $27.1 \%$ dijelaskan oleh variabel lainnya yang tidak ada pada model penelitian ini. Kemudian variabel manajemen pengetahuan juga mampu menjelaskan keragaman variabel kualitas pelayanan karena memiliki nilai sebesar $96.5 \%$ dan sisanya $3.5 \%$ dijelaskan oleh variabel lain yang tidak ada pada model penelitian ini. Nilai yang didapat dalam perhitungan Goodness of Fit (GOF) sebesar 0.990. Hal ini menunjukan 
bahwa variabel manajemen pengetahuan dan inovasi didalam model penelitian ini dapat menjelaskan variabel kualitas pelayanan secara keseluruhan dengan fit serta mampu mencerminkan realitas dan fenomena dalam penelitian ini. Dapat disimpulkan bahwa dalam penelitian ini sudah sangat baik untuk dijadikan model penelitian karena nilai $\mathrm{Q}^{2}$ mendekati 1. Semakin tinggi nilai Goodness of Fit (GOF) dalam sebuah model penelitian maka semakin baik model yang diajukan.

Tabel 4. Tabel Uji Hipotesis pengaruh dalam model

\begin{tabular}{|c|c|c|c|}
\hline Peubah laten & $\begin{array}{c}\text { Original } \\
\text { sample }(\mathbf{O})\end{array}$ & $\begin{array}{c}\text { T-Statistic } \\
(\mid \text { O/STERR } \mid)\end{array}$ & Keterangan \\
\hline $\begin{array}{l}\text { Manajemen } \\
\text { pengetahuan (X1) } \\
\text { terhadap Inovasi (X2) }\end{array}$ & 0.854 & 30.748 & $\begin{array}{l}\text { Hipotesis } \\
\text { diterima/signifikan }\end{array}$ \\
\hline $\begin{array}{l}\text { Manajemen } \\
\text { pengetahuan }(\mathrm{X} 1) \\
\text { terhadap kualitas } \\
\text { pelayanan }(\mathrm{Y})\end{array}$ & -0.036 & 0.853 & $\begin{array}{l}\text { Hipotesis ditolak/ } \\
\text { tidak signifikan }\end{array}$ \\
\hline $\begin{array}{l}\text { Inovasi }(\mathrm{X} 2) \text { terhadap } \\
\text { kualitas pelayanan } \\
(\mathrm{Y})\end{array}$ & 1.009 & 28.303 & $\begin{array}{l}\text { Hipotesis diterima/ } \\
\text { signifikan }\end{array}$ \\
\hline
\end{tabular}

Sumber: (Data proses, 2019)

Hasil Uji pengaruh (Uji Hipotesis). Dalam pengujian hipotesis ini akan menjelaskan masing-masing hipotesis dalam penelitian ini secara komperhensif. Pengujian hipotesis yang sudah dihasilkan menggunakan teknik Bootstraping juga akan merincikan masing masing koefisien jalur dan interpretasi secara mendalam di penelitian ini. Berikut rincian masing-masing hipotesis dan interpretasinya.

Hipotesis pertama (H1): Manajemen pengetahuan memiliki pengaruh positif dan signifikan terhadap inovasi pada RSUD Drajat Prawiranegara Kabupaten Serang. Hasil Bootstraping yang sudah dilakukan dalam penelitian ini menunjukan nilai statistik bahwa terdapat hubungan dan pengaruh antara manajemen pengetahuan terhadap inovasi dengan nilai t-statistik sebesar 30.748 yang lebih besar dari 1.98 atau $>1.98$. Hipotesis pertama dengan demikian diterima karena memenuhi syarat. Bisa disimpulkan manajemen pengetahuan berpengaruh positif dan signifikan sebesar 0.854 , dan dengan penerapan manajemen pengetahuan yang optimal maka akan meningkatkan inovasi dalam bidang pelayanan kesehatan pada RSUD Drajat Prawiranegara Kabupaten Serang. Manajemen pengetahuan menjadi hal yang penting dalam meningkatkan inovasi. Hal ini harus menjadi perhatian khusus bagi pihak rumah sakit untuk terus berkembang dengan inovasi pelayanan kesehatan. Pengelolaan pengetahuan bagi tenaga kerja kesehatan efektif dalam menciptakann ide inovasi pelayanan kesehatan. Dengan pengembangan pengetahuan akan menciptakan inovasi yang nantinya akan memperbaiki pelayanan kesehatan pada RSUD Drajat Prawiranegara Kabupaten Serang. Pendekatan manajemen pengetahuan baik dari proses mendapatkan pengetahuan, proses memilih pengetahuan, proses berbagi pengetahuan dan proses penerapan pengetahuan menjadi hal penting dalam menciptakan inovasi dalam proses pelayanan kesehatan. 
Hipotesis pertama (H2): Manajemen pengetahuan memiliki pengaruh positif dan signifikan terhadap kualitas pelayanan pada RSUD Drajat Prawiranegara Kabupaten Serang. Hasil Bootstraping yang sudah dilakukan dalam penelitian ini menunjukan nilai statistik bahwa tidak terdapat pengaruh yang signifikan antara manajemen pengetahuan terhadap kualitas pelayanan dengan nilai t-statistik sebesar 0.853 yang lebih kecil dari 1.98 atau < 1.98. Hipotesis kedua dengan demikian ditolak karena tidak memenuhi syarat. Bisa disimpulkan pihak RSUD Drajat Prawiranegara Kabupaten Serang belum memanfaatkan manajemen pengetahuan dengan baik untuk menciptakan kualitas pelayanan yang optimal dalam melaksanakan pelayanan kesehatan. Tenaga kerja kesehatan RSUD Drajat Prawiranegara Kabupaten Serang dalam pengujian hipotesis ini menunjukan belum mampu mengolah manajemen pengetahuan dengan baik dalam menciptakan kualitas pelayanan kesehatan. Hal ini didukung dengan hasil wawancara berupa keluhan dari pasien rawat inap dan rawat jalan. Hasil ini juga diharapkan menjadi rujukan bagi pihak rumah sakit dalam mengolah sumber daya manusia khususnya dalam mengembangkan pengetahuan yang sudah ada dan dalam menciptakan pengetahuan yang baru untuk mencapai kualitas pelayanan kesehatan yang optimal.

Hipotesis pertama (H3): Inovasi memiliki pengaruh positif dan signifikan terhadap kualitas pelayanan pada RSUD Drajat Prawiranegara Kabupaten Serang. Hasil Bootstraping yang sudah dilakukan dalam penelitian ini menunjukan nilai statistik bahwa terdapat hubungan dan pengaruh antara Inovasi terhadap kualitas pelayanan dengan nilai t-statistik sebesar 28.303 yang lebih besar dari 1.98 atau > 1.98. Hipotesis ketiga dengan demikian diterima karena memenuhi syarat. Bisa disimpulkan inovasi berpengaruh positif dan signifikan sebesar 1.009. Dengan mengoptimalkan inovasi pelayanan kesehatan maka akan meningkatkam kualitas pelayanan kesehatan pada RSUD Drajat Prawiranegara Kabupaten Serang. Hasil hipotesis ini menjadi pertimbangan rumah sakit dalam meningkatkan kualitas pelayanan. Tugas rumah sakit dalam menciptakan layanan kesehatan yang optimal harus mengedepankan inovasi yang nantinya akan berguna untuk memperbaiki pelayanan kesehatan. Kualitas pelayanan akan optimal dengan dukungan pihak rumah sakit dengan mempertimbangkan pelayanan kesehatan dari tenaga kerja di RSUD Drajat Prawiranegara Kabupaten Serang. Inovasi menjadi hal penting dalam menciptakan kualitas pelayanan. Tujuan inovasi dalam pelayanan kesehatan itu sendiri bertujuan untuk menciptakan pelayanan kesehatan yang prima. Pengunjung rumah sakit yaitu pasien rawat inap dan rawat jalan akan terbantu dengan adanya inovasi dan citra rumah sakit akan semakin baik dengan kualitas pelayanan yang prima.

Implikasi Manajerial. Dari hasil analisis dalam penelitian ini menunjukan bahwa terdapat pengaruh manajemen pengetahuan terhadap inovasi dan inovasi terhadap kualitas pelayanan. Tidak terdapat pengaruh langsung dan signifikan antara manajemen pengetahuan terhadap kualitas pelayanan. Tiga temuan tersebut yang mewakili penelitian ini. Manajemen pengetahuan yang dicerminkan oleh proses mendapatkan pengetahuan yaitu dimana tenaga kerja rumah sakit memperoleh pengetahuan dari dalam atau luar tempat kerja mereka. Pihak internal rumah sakit diharapkan dapat mendukung tenaga kerja dalam proses pendapatan pengetahuan. Salah satu langkah rumah sakit dalam mendukung proses mendapatkan pengetahuan yaitu dengan mengadakan pelatihan. Pelatihan secara konprehensif yang diberikan pihak rumah sakit sangat berguna untuk seluruh tenaga kerja, hal ini bertujuan untuk meningkatkan skill serta pengetahuan 
seputar pelayanan kesehatan publik. Pengalaman dalam proses kerja bagi tenaga kerja juga sangat berpengaruh dalam penciptaan pengetahuan baru. Pengalaman menjadi faktor dalam proses mendapatkan pengetahuan dari luar atau eksternal bagi tenaga kerja rumah sakit Drajat Prawiranegara Kabupaten Serang.

Inovasi merupakan salah satu faktor penting dalam sebuah pelayanan kesehatan publik. Inovasi akan mengarahkan organisasi pemerintah pada perubahan organisasi di dalam lingkungan yang dinamis. Mengembangkan sebuah budaya inovasi akan mengarah kepada fleksibilitas organisasi dengan kepentingan tertentu dalam modernisasi program di sektor publik (Sangkala, 2013). Dalam inovasi pelayanan kesehatan pihak rumah sakit Drajat Prawiranegara Kabupaten Serang diharapkan agar menerapkan pelayanan baru yang lebih efiseien dalam proses administrasi. Dengan dukungan sistem inovasi yang berbasis komputer menjadi hal yang penting pada saat ini. Inovasi tidak terlepas dari pengetahuan, karena ide baru dalam proses pelayanan kesehatan dipengaruhi oleh sumber daya manusia yang ada pada rumah sakit. Semakin baik pengelolaan sumber daya manusia dalam manajemen pengetahuan akan semakin besar membuka peluang ide inovasi yang optimal bagi pihak rumah sakit Drajat Prawiranegara Kabupaten Serang. Pada peraktiknya pihak rumah sakit harus konsisten dalam mengelola sumber daya manusia. Pihak rumah sakit dan tenaga kerja harus saling bersama-sama mengembangkan inovasi yang ditunjang dengan pengelolaan pengetahuan yang baik. Kualitas pelayanan yang optimal bisa diterapkan apabila proses inovasi dan manajemen pengetahuan dijalankan dengan baik oleh pihak internal rumah sakit Drajat Prawiranegara Kabupaten Serang dan tenaga kerjanya.

Kualitas pelayanan yang baik merupakan tujuan dari penyedia jasa pelayanan. Rumah sakit Drajat Prawiranegara Kabupaten Serang sebagai penyedia layanan kesehatan publik bagi masyarakat di wilayah sekitar Kabupaten Serang dituntut agar selalu memberikan pelayanan terbaik. Untuk menciptakan kualitas pelayanan yang optimal pihak rumah sakit diharapkan agar memperhatikan infrastruktur, kualitas personel yaitu penyaluran pelayanan dari Dokter, tenaga medis dan tenaga non medis. Proses pelayanan kesehatan dan prosedur administrasi juga akan menunjang terciptanya kualitas pelayanan yang optimal. Tanggung jawab sosial menjadi indikator yang harus ditingkatkan oleh pihak rumah sakit.

\section{KESIMPULAN}

Simpulan Dari hasil analisis dalam penelitian ini menyimpulkan bahwa manajemen pengetahuan memiliki pengaruh yang positif dan signifikan terhadap inovasi pada RSUD Drajat Prawiranegara Kabupaten Serang. Pihak rumah sakit dapat meningkatkan inovasi dalam pelayanan kesehatan dengan menerapkan manajemen pengetahuan yang optimal. Dengan penerapan manajemen pengetahuan yang baik akan tercipta ide dan kreatifitas dari tenaga kerja dalam menciptakan inovasi pelayanan kesehatan.

Manajemen pengetahuan tidak dapat berpengaruh langsung terhadap kualitas pelayanan pada RSUD Drajat Prawiranegara Kabupaten Serang. Pengelolaan manajemen pengetahuan belum optimal dalam meningkatkan kualitas pelayanan. Pihak rumah sakit diharapkan dapat meningkatkan penerapan serta menjalankan manajemen pengetahuan khususnya proses mendapatkan pengetahuan agar dapat meningkatkan kualitas pelayanan. Inovasi berpengaruh positif dan signifikan terhadap kualitas pelayanan pada 
RSUD Drajat Prawiranegara Kabupaten Serang. Pihak rumah sakit dapat meningkatkan inovasi seiring dengan perkembangan jaman pada saat ini dan terus meningkatkan kualitas pelayanan.

Saran Berdasarkan kesimpulan dalam penelitian ini, saran yang dapat diterapkan oleh RSUD Drajat Prawiranegara Kabupaten Serang yaitu menerapkan manajemen pengetahuan dan inovasi secara optimal sehingga dapat meningkatkan kualitas pelayanan. RSUD Drajat Prawiranegara Kabupaten Serang sebagai penyedia layanan kesehatan publik harus terus dapat meningkatkan kualitas pelayanan. Dengan meningkatkan kualitas pelayanan diharapkan dapat menjawab tuntutan masyarakat untuk selalu memberikan pelayanan kesehatan yang optimal. Pengelolaan sumber daya manusia di rumah sakit Drajat Prawiranegara harus dilakukan secara komperhensif. Kerja sama antar bidang kerja, baik itu tenaga kerja medis, dokter dan non medis harus optimal dalam menghadapi tantangan serta tuntutan dari perubahan pelayanan kesehatan. Tenaga kerja rumah sakit juga harus aktif memberikan ide atau kreatifitas demi terciptanya inovasi atau perbaikan inovasi yang sudah ada, pada RSUD Drajat Prawiranegara Kabupaten Serang. Bagi peneliti, diharapkan dapat mempertimbangkan dan menambah variabel lain diluar variabel yang sudah ada dalam penelitian ini serta menambah referensi jurnal.

\section{DAFTAR PUSTAKA}

Choi, J. H. (2006). The Relationship Among Transformational Leadership, Organizational Outcomes, And Service Quality In The Five Major NCAA Conferences. A Record Of Study Submitted To The Office Of Graduate Studies Of Texas A\&M University, In Partial Fulfillment Of The Requirements For The Degree Of Doctor Of Education.

Dalkir, K. (2005). Knowledge Management In Theory and Practice. USA Linacre. House, Jordan Hill, Oxford OX2 8DP, UK Elsevier Butterworth-Heinemann

Duggirala, M Rajendran C, Anantharaman, R. N. (2008). Patient-Perceived Dimensions Of Total Quality Service In Healthcare. Benchmarking: An International Journal. 15 (5): 560-583.

Edvardsson, Bard. (2013). A new conceptualization of service innovation grounded in S-D logic and service systems. International Journal of Quality and Service Sciences. Vol. 5 Iss 1.

Ghozali I. (2008). Structural equation modeling metode alternatif dengan partial least square. Edisi 2. Semarang (ID): badan penerbit diponegoro.

Hafizurrachman. (2012). Kebijakan Keperawatan Berbasis Kinerja di RSU Tangerang. Jurnal Manajemen Kesehatan. Vol. 15, No. 1 Maret 2012.

Hamzani Fadil. (2015). The Influence of Organizational Innovation towards Internal Service Quality in MBKS. International Research Symposium in Service Management. IRSSM-6 Social and Behavioral Sciences 224 ( 2016 ) 317 - 324.

Huang CY, Shih, HuiChuan, (2013). A new mode of learning organization. International Journal of Manpower. Vol. 32 No. 5/6.

Ing-Long Wu. (2018). Open innovation based knowledge management implementation: a mediating role of knowledge management design. Journal of Knowledge Management. ISSN 1367-3270 
Jennex E. (2007). Knowledge Management in Modern Organizations. Idea Group Publishing. San Diego

Jonirasmanto. (2009). Mutu Pelayanan Kesehatan: Ambivalensi Antara Kewajiban Dan Keinginan (Antara Penyelenggara Dan Pemilik). Hal Mutu Pelayanan Rumah Sakit/05.11.

Jussi. (2012). Knowledge management practices in healthcare services. Measuring Business Excellence. vol. 16 NO. 4 2012, pp. 54-65, Q Emerald Group Publishing Limited, ISSN 1368-3047.

Luthans, F. (2006). Perilaku Organisasi. Edisi Sepuluh. Penerbit Andi. Yogyakarta.

Mukherjee A, Malhotra N. (2006). Does Role Clarity Explain Employee-Perceived Service Quality?, A Study Of Antecedents And Consequences In Call Centres. International Journal Of Service Industry Management. 17 (5): 444-473.

Nawawi I. (2012). Manajemen Pengetahuan (Knowledge Management): Teori dan Aplikasi dalam Mewujudkan Daya Saing Organisasi Bisnis dan Publik. Bogor (ID): Ghalia Indonesia.

Nonaka, Takeuchi. (2004). Knowledge Creation and Dialectics. Hitosubashi on Knowledge Management.Oleh Hirotaka Takeuchi dan Ikujiro Nonaka. Singapore: John Wiley \& Sons (Asia), hlm.1-27.

Padma, Rajendran, Lokachari. (2013). Service quality and its impact on customer satisfaction in Indian hospitals-Perspectives of patients and their attendants. Benchmarking: An International Journal. Vol. 17 No. 6, 2010

Rogers EM. (2003). Diffusion of Innovations $5^{\text {th }}$ edition, Free Press. New York.

Salim MI, and Sulaeman M. (2013). Organizational learning, innovation and performance: a study of Malaysian small and medium sized enterprises. International Journal of Business and Management. Vol. 6, No. 12.

Sangkala. (2013). Knowladge Management (sebuah pengantar bagaimana organisasi mengelola pengetahuan sehingga menjadi organisasi yangunggul. Jakarta. RajaGrafindo Persada.

Tidd. (2001). Managing Innovation: Integratin technological, market and organization change. 2nd ed Chichester, John Wiley.

Townsend K and Wilkinson A. (2010). Managing under pressure: HRM in hospitals. Human Resource Management Journal. 20(4): 332-8.

Xiaomi An. (2014). Knowledge management in supporting collaborative innovation community capacity building. Journal of Knowledge Management. Vol. 18 Issue: 3. 